Article

\title{
Oligomerization of Butene Mixture over NiO/Mesoporous Aluminosilicate Catalyst
}

\author{
Donggun Lee ${ }^{1}$, Hyeona Kim ${ }^{1}$, Young-Kwon Park ${ }^{2}$ and Jong-Ki Jeon ${ }^{1, *}$ \\ 1 Department of Chemical Engineering, Kongju National University, Cheonan 31080, Korea; \\ dglee0527@smail.kongju.ac.kr (D.L.); dbd99115@gmail.com (H.K.) \\ 2 School of Environmental Engineering, University of Seoul, Seoul 02504, Korea; catalica@uos.ac.kr \\ * Correspondence: jkjeon@kongju.ac.kr; Tel.: +82-41-521-9363
}

Received: 29 August 2018; Accepted: 11 October 2018; Published: 16 October 2018

\begin{abstract}
This study is aimed at preparing $\mathrm{C}_{8}-\mathrm{C}_{16}$ alkene through oligomerization of a butene mixture using nickel oxide supported on mesoporous aluminosilicate. Mesoporous aluminosilicate with an ordered structure was successfully synthesized from HZSM- 5 zeolite by combining a top-down and a bottom-up method. MMZ $Z_{\mathrm{ZSM}-5}$ catalyst showed much higher butene conversion and $\mathrm{C}_{8}-\mathrm{C}_{16}$ yield in the butene oligomerization reaction than those with HZSM-5. This is attributed to the pore geometry of $\mathrm{MMZ}_{\mathrm{ZSM}-5}$, which is more beneficial for internal diffusion of reactants, reaction intermediates, and products. The ordered channel-like mesopores were maintained after the nickel-loading on $M M Z_{Z S M-5}$. The yield for $\mathrm{C}_{8}-\mathrm{C}_{16}$ hydrocarbons over $\mathrm{NiO} / \mathrm{MMZ}_{\mathrm{ZSM}-5}$ was higher than that of $M M Z_{Z S M-5}$ catalyst, which seemed to be due to higher acid strength from a higher ratio of Lewis acid to Brønsted acid. The present study reveals that a mesoporous $\mathrm{NiO} / \mathrm{MMZ}_{\mathrm{ZSM}-5}$ catalyst with a large amount of Lewis acid sites is one of the potential catalysts for efficient generation of aviation fuel through the butene oligomerization.
\end{abstract}

Keywords: butene; oligomerization; aviation fuel; mesoporous aluminosilicate; nickel

\section{Introduction}

The greenhouse gas (GHG) emitted when an aircraft is in operation has negative impacts on the environment, including global warming [1]. To resolve such problems, the International Civil Aviation Organization announced a policy intended to reduce GHG emission by aircraft using biomass-derived fuels for aircraft [2]. Consequently, research about synthesis of aviation fuel from biomass is drawing attention. The Alcohol to Jet (ATJ) process for making alcohol from biomass as feedstock and for making aviation fuel from alcohol has recently attracted attention [3]. This process involves the production of butene through the dehydration of butanol, the synthesis of higher olefins by oligomerization of the newly produced butene, and hydrogenation of the higher olefins [4-6]. Studies on the synthesis of butenes through butanol dehydration in the first step are already under way [7-11]. We have previously reported that silica-based, solid acid catalysts with mesopores and highly dispersed metal oxide catalysts are effective in the production of butene by butanol dehydration [12,13].

Because the demand for aviation fuel is increasing steadily, maximizing the production of aviation fuel is of great interest to oil refining companies [14]. Because butene is an excess in the refineries (FCC), the use of oligomerization to convert butene into aviation fuel is a promising method for the generation of aviation fuel.

The butene oligomerization reaction has been studied mainly using zeolites or heterogeneous catalysts [14-19]. Yoon et al. found that ferrierite, zeolite beta, and Amberlyst-35 exhibited high catalytic performance for the trimerization of isobutene [20-22]. It is also known that a catalyst loaded with nickel on Y zeolite or ZSM-5 is effective for trimerization of linear butene [23-26]. 
We have been studying the application of mesoporous aluminosilicate with zeolite framework for catalytic reaction. In particular, we have published research results in which a framework was constructed using commercial zeolite. From this, mesoporous aluminosilicate with a well-ordered structure was produced by combining a top-down method and a bottom-up method [13,27].

The purpose of this study was to prepare a particular fraction $\left(\mathrm{C}_{8}-\mathrm{C}_{16}\right.$; corresponding to aviation fuel) through oligomerization of butene using nickel oxide supported on mesoporous aluminosilicate with a well-ordered structure. We used a butene mixture having the same composition as the product obtained from dehydration of butanol as raw material for the oligomerization. High-pressure oligomerization of the butene mixture was investigated in a fixed-bed continuous-flow reactor.

\section{Results and Discussion}

\subsection{Textural Properties of Catalysts}

The $\mathrm{N}_{2}$ adsorption-desorption isotherm of $\mathrm{MMZ}_{\mathrm{ZSM}-5}$ (Figure 1) showed a type IV(a) physisorption isotherm in the IUPAC classification [28,29]. Furthermore, the $\mathrm{N}_{2}$ adsorption-desorption isotherm of $\mathrm{MMZ}_{\mathrm{ZSM}-5}$ exhibited the $\mathrm{H} 4$ type of hysteresis loop, which is typical of mesoporous zeolites and micro-mesoporous materials [29,30]. In the case of $\mathrm{NiO} / \mathrm{MMZ}_{\mathrm{ZSM}-5}$ catalyst, the characteristics of $\mathrm{N}_{2}$ physisorption isotherm were not much different from the $\mathrm{N}_{2}$ adsorption-desorption isotherm of MMZ ZSM-5. This indicates that the geometry of the ordered mesopores of $\mathrm{MMZ}_{\mathrm{ZSM}-5}$ was not changed by $\mathrm{NiO}$ loading.

The pore size distribution curves of the three catalysts were compared in Figure 2. As expected from the nitrogen adsorption isotherm, it was difficult to observe the mesopores of HZSM-5, while a mesopore peak of about $3.0 \mathrm{~nm}$ could be observed on $\mathrm{MMZ}_{\mathrm{ZSM}-5}$. Moreover, the pore size somewhat decreased after the nickel loading of $9 \mathrm{wt} \%$. However, the overall characteristic pore-size distribution curve of the material did not change after $\mathrm{NiO}$ loading.

The BET surface areas of MMZ ZSM-5 and HZSM-5 were 745 and $448 \mathrm{~m}^{2} / \mathrm{g}$, respectively (Table 1). Furthermore, the total pore volumes of MMZ $Z_{Z S M-5}$ and HZSM- 5 were 0.47 and $0.19 \mathrm{~cm}^{3} / g$, respectively. Therefore, it was clear that the BET surface area and pore size of $M M_{Z S M-5}$ catalyst were much larger than those of HZSM- 5 catalyst. Meanwhile, the BET surface area and pore volume of MMZZSM-5 decreased slightly after the $\mathrm{NiO}$ loading, which was due to the fact that the nickel oxide was attached to the pore surface and partially blocked a pore mouth.

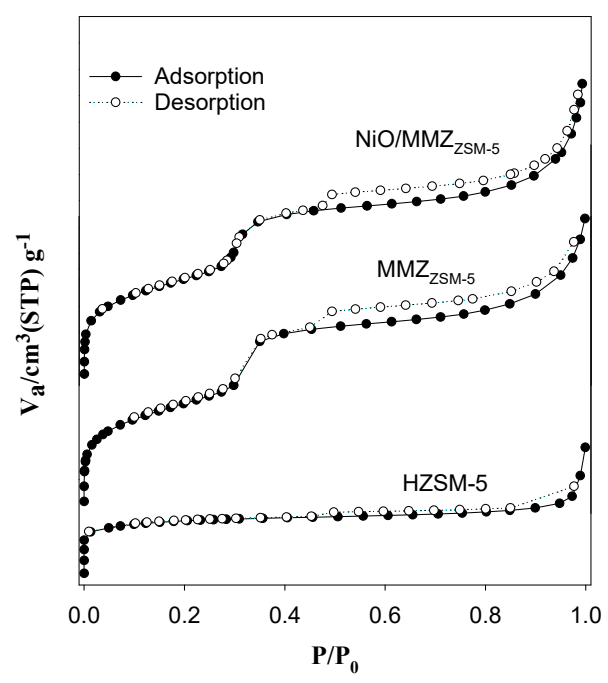

Figure 1. $\mathrm{N}_{2}$ adsorption-desorption isotherms of various catalysts. 


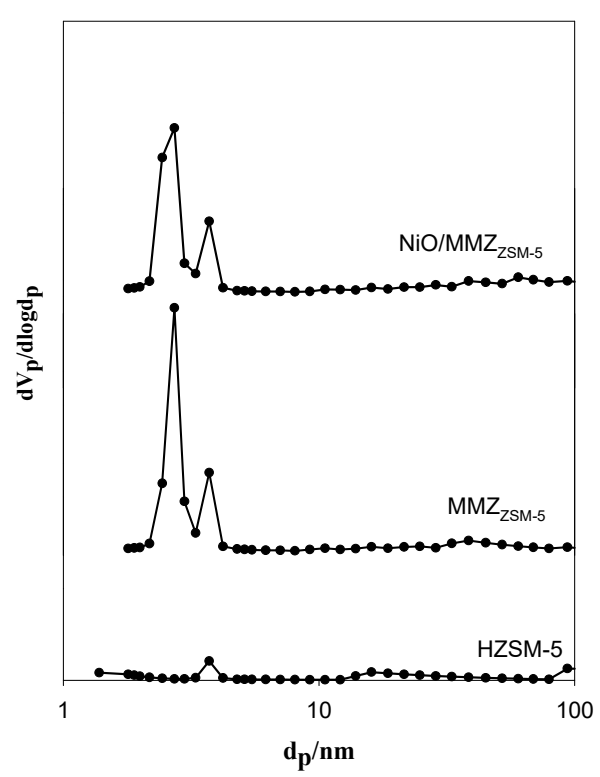

Figure 2. Pore size distribution of various catalysts.

Table 1. Textural properties of the catalysts.

\begin{tabular}{|c|c|c|c|}
\hline Zeolite Type & $\mathrm{S}_{\mathrm{BET}}\left(\mathrm{m}^{2} \mathrm{~g}^{-1}\right)$ & $V_{P}\left(\mathrm{~cm}^{3} \mathrm{~g}^{-1}\right)^{a}$ & $\mathrm{D}_{\mathrm{P}}(\mathrm{nm})^{b}$ \\
\hline HZSM-5 & 448 & 0.19 & - \\
\hline $\mathrm{MMZ}_{\mathrm{ZSM}-5}$ & 745 & 0.47 & 2.7 \\
\hline $\mathrm{NiO} / \mathrm{MMZ}_{\mathrm{ZSM}-5}$ & 726 & 0.43 & 2.7 \\
\hline
\end{tabular}

a Total pore volume measured at $p / p_{0}=0.99 .{ }^{\mathrm{b}}$ Average pore diameter determined by the $\mathrm{BJ} H$ method.

Low-angle XRD patterns of the $\mathrm{MMZ}_{\mathrm{ZSM}-5}$ and $\mathrm{NiO} / \mathrm{MMZ}_{\mathrm{ZSM}-5}$ catalysts are presented in Figure 3. MMZ $Z_{Z S M-5}$ has three diffraction peaks corresponding to 100,110 , and 200 Bragg reflections, respectively. In particular, the peak at $2 \theta$ of $2.3^{\circ}$ is the characteristic peak of the 2-D hexagonal structure, and the two weak peaks at $3.9^{\circ}$ and $4.5^{\circ}$ show the inherent characteristics of the mesoporous material [27]. The $\mathrm{NiO} / \mathrm{MMZ}_{\mathrm{ZSM}-5}$ sample represents the characteristic peaks of $\mathrm{MMZ}_{\mathrm{ZSM}-5}$ with three intense peaks at $2 \theta=2.3^{\circ}, 3.9^{\circ}$, and $4.5^{\circ}$, respectively. After nickel loading, the XRD patterns of the material showed a slight reduction in peak intensity but maintained the same patterns as those of $M M Z_{Z S M-5}$. This suggests that the ordered mesoporous structures of the $M M Z_{Z S M-5}$ are well retained after the nickel loading. The $\mathrm{XRD}$ patterns of $\mathrm{MMZ}_{\mathrm{ZSM}-5}$ and $\mathrm{NiO} / \mathrm{MMZ}_{\mathrm{ZSM}-5}$ material in the high-angle region (Figure 4) give a broad line centered at $2 \theta \approx 23^{\circ}$, which indicates that the framework of MMZ ZSM-5 was not atomically ordered and the starting source, HZSM-5, was not present in the MMZZSM-5 material.

A TEM image is presented in Figure 5 to determine whether $\mathrm{MMZ}_{\mathrm{ZSM}-5}$ and NiO/MMZ $\mathrm{ZSM}_{\mathrm{ZS}-5}$ have hexagonal structures. $M M Z_{Z S M-5}$ has a well-ordered structure with mesopores that are hexagonal 1-D channels [31]. The $\mathrm{NiO} / \mathrm{MMZ}_{\mathrm{ZSM}-5}$ sample maintained the structural features of $\mathrm{MMZ}_{\mathrm{ZSM}-5}$ after the nickel loading. 


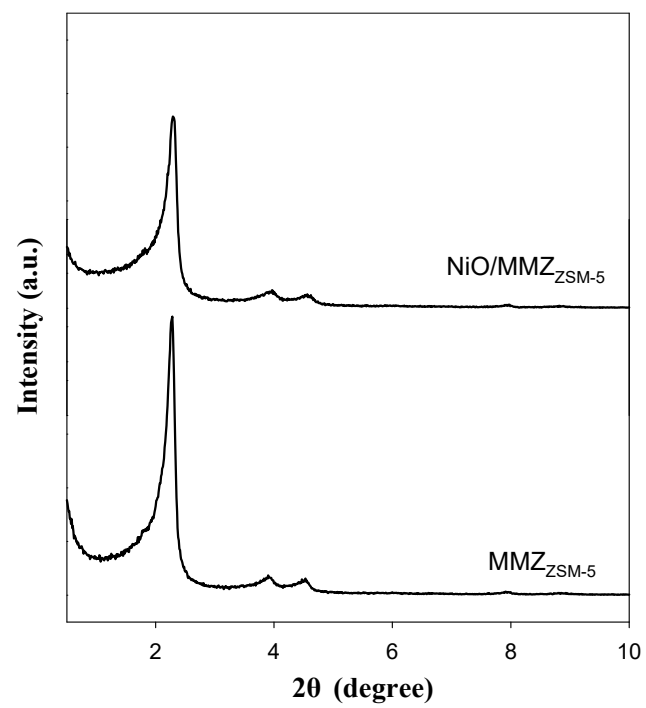

Figure 3. Low-angle XRD patterns of $\mathrm{MMZ}_{\mathrm{ZSM}-5}$ and NiO/MMZ $\mathrm{ZSM}-5$.

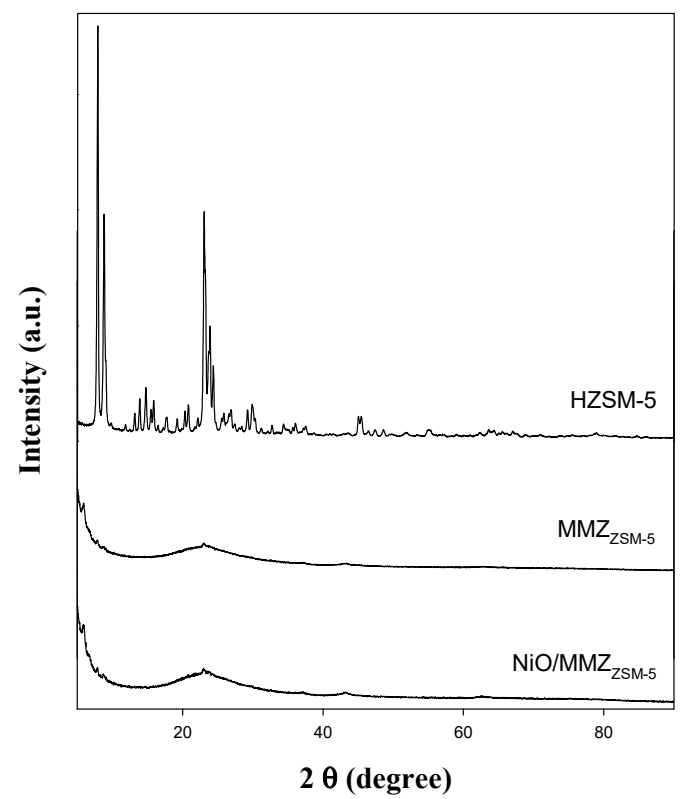

Figure 4. High angle XRD patterns of HZSM-5, MMZ $\mathrm{ZSM-5}$, and NiO/MMZ $\mathrm{ZSM}-5$.

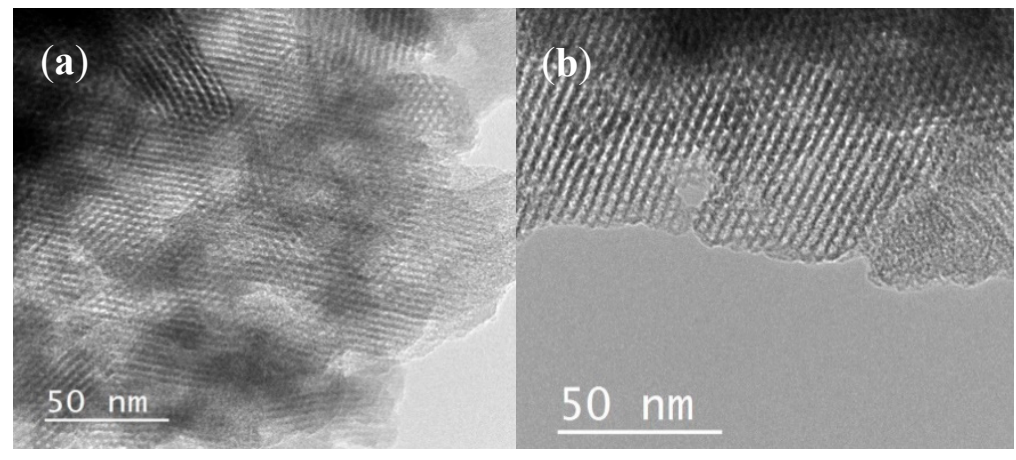

Figure 5. TEM image of (a) $M M Z_{Z S M-5}$ and (b) NiO/MMZ

\subsection{Acid Properties of Catalysts}

The acidic characteristics of HZSM-5, MMZ ZSM-5, and NiO/MMZ ZSM-5 were analyzed using $\mathrm{NH}_{3}$-TPD (Figure 6). HZSM-5 exhibits two peaks at the desorption temperature of ammonia near 
180 and $380^{\circ} \mathrm{C}$, indicating that weak strength acid sites and medium strength acid sites are widely distributed. The $\mathrm{NH}_{3}$-TPD curve of $\mathrm{MMZ}_{\mathrm{ZSM}-5}$ shows that the peak intensity is greatly reduced compared to HZSM-5. This indicates that MMZ ZSM-5 has both the weak acid sites near $170{ }^{\circ} \mathrm{C}$ and medium strength acid near $340{ }^{\circ} \mathrm{C}$, but the total amount of acid sites over MMZ $\mathrm{ZSM}_{\mathrm{ZS} 5}$ is greatly reduced compared to HZSM- 5 . The reason could be that aluminum is relatively less exposed to the amorphous framework that constructs the pore walls of $M \mathrm{MZZ}_{\mathrm{ZSM}-5}$. On the other hand, in the case of the $\mathrm{MMZ}_{\mathrm{ZSM}-5}$ catalyst, the peak temperature of $\mathrm{NH}_{3}$-TPD shifted to a lower temperature than that of HZSM-5, which means that the acid strength was also weakened.

For the NiO/MMZ $\mathrm{ZSM}_{-5}$ catalyst, the desorption peak at a low temperature shifted to high temperature $\left(210{ }^{\circ} \mathrm{C}\right)$, indicating that the acid strength of $\mathrm{NiO} / \mathrm{MMZ}_{\mathrm{ZSM}-5}$ is higher than that of $M M Z_{Z S M-5}$ catalyst. It is noticeable that an additional high-temperature $\left(540{ }^{\circ} \mathrm{C}\right)$ peak appeared on the $\mathrm{NH}_{3}$-TPD profile of the $\mathrm{NiO} / \mathrm{MMZ}_{\mathrm{ZSM}-5}$ catalyst, which means that nickel oxide generates a new type of acid site. This high-temperature peak is known to be attributable to Lewis acid sites from nickel oxide [32].

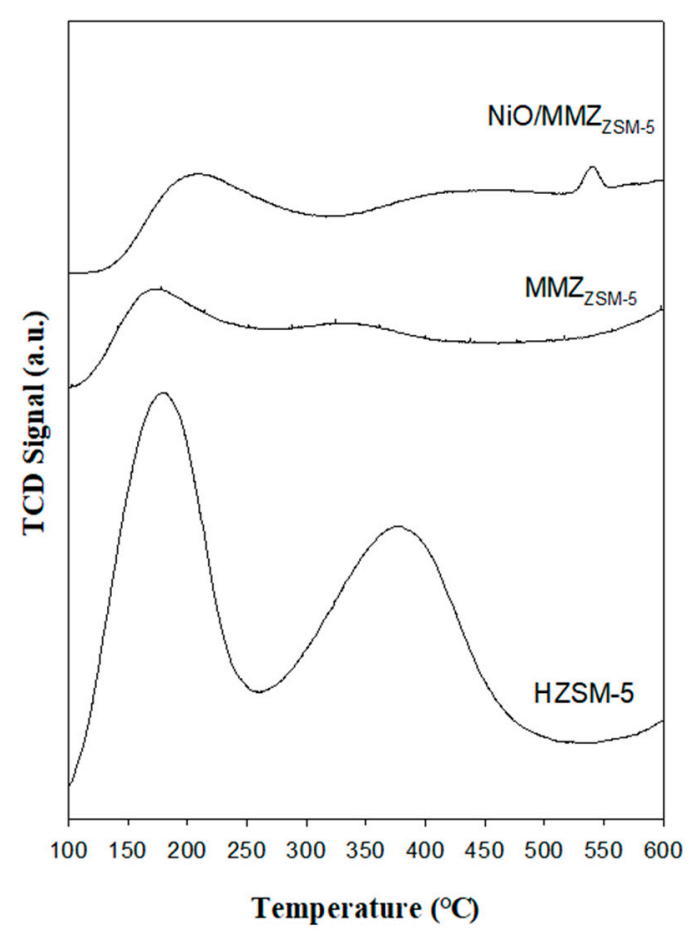

Figure 6. $\mathrm{NH}_{3}$-TPD profiles of various catalysts.

Figure 7 shows the results of the pyridine-FTIR for the NiO/MMZ $\mathrm{ZSM}_{\mathrm{ZS}}$ sample. As the desorption temperature increased to $300{ }^{\circ} \mathrm{C}$, the band intensity at $1596 \mathrm{~cm}^{-1}$ diminished drastically and disappeared at temperatures higher than $150^{\circ} \mathrm{C}$, indicating a very weak $\mathrm{H}$ acid site $[33,34]$. Four well-resolved bands can be observed at $\left(1450,1491,1542\right.$, and 1610) $\mathrm{cm}^{-1}$ at higher than $150{ }^{\circ} \mathrm{C}$. Two of these bands are attributed to Lewis sites $\left(1450\right.$ and $\left.1610 \mathrm{~cm}^{-1}\right)$, while the band at $1542 \mathrm{~cm}^{-1}$ corresponds to the Brönsted sites [33,34]. Additional band near $1491 \mathrm{~cm}^{-1}$ is associated with a Lewis site and Brönsted site simultaneously.

The pyridine-FTIR results of HZSM-5, MMZ $\mathrm{ZSM-5}$, and NiO/MMZ Figure 8. HZSM-5 is rich in Brönsted sites $\left(1542 \mathrm{~cm}^{-1}\right)$ and also has Lewis sites $\left(1450 \mathrm{~cm}^{-1}, 1610 \mathrm{~cm}^{-1}\right)$. In MMZ ZSM-5 also, both Brönsted and Lewis acidity can be observed. It should also be noted that for the $\mathrm{NiO} / \mathrm{MMZ}_{\mathrm{ZSM}-5}$ catalyst, the band corresponding to the Lewis acid site $\left(1450 \mathrm{~cm}^{-1}\right)$ was much larger than that associated with the Brönsted site $\left(1542 \mathrm{~cm}^{-1}\right)$. That is, the $\mathrm{NiO}$ loading shows that the Lewis site is relatively increased. The pyridine-FTIR and $\mathrm{NH}_{3}$-TPD results suggest that a new acid site is generated by loading of $\mathrm{NiO}$ over $\mathrm{MMZ}_{\mathrm{ZSM}-5}$, which is attributable to the Lewis site. 


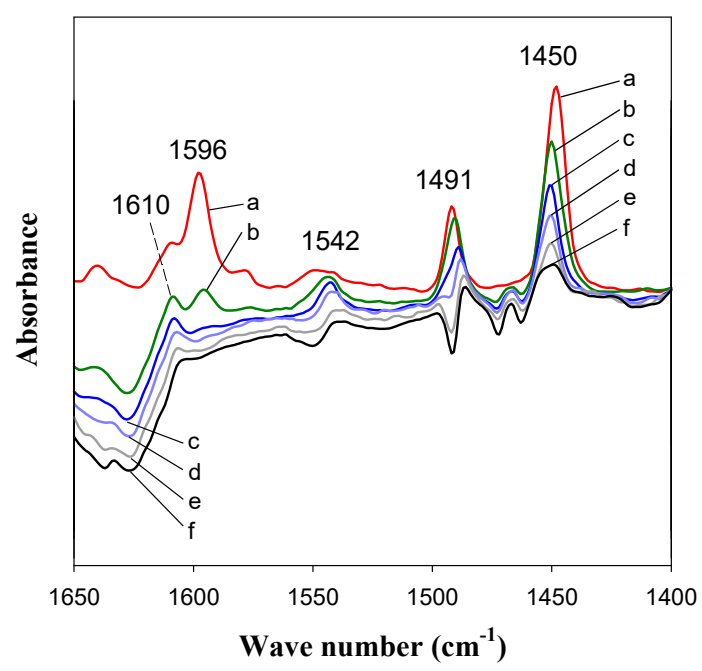

Figure 7. Pyridine-FTIR spectra over $\mathrm{NiO} / \mathrm{MMZ}_{\mathrm{ZSM}-5}$ under a vacuum (a: room temperature, $\mathrm{b}: 100{ }^{\circ} \mathrm{C}$, c: $150{ }^{\circ} \mathrm{C}$, d: $200{ }^{\circ} \mathrm{C}$, e: $250{ }^{\circ} \mathrm{C}$, and f: $300{ }^{\circ} \mathrm{C}$ ).

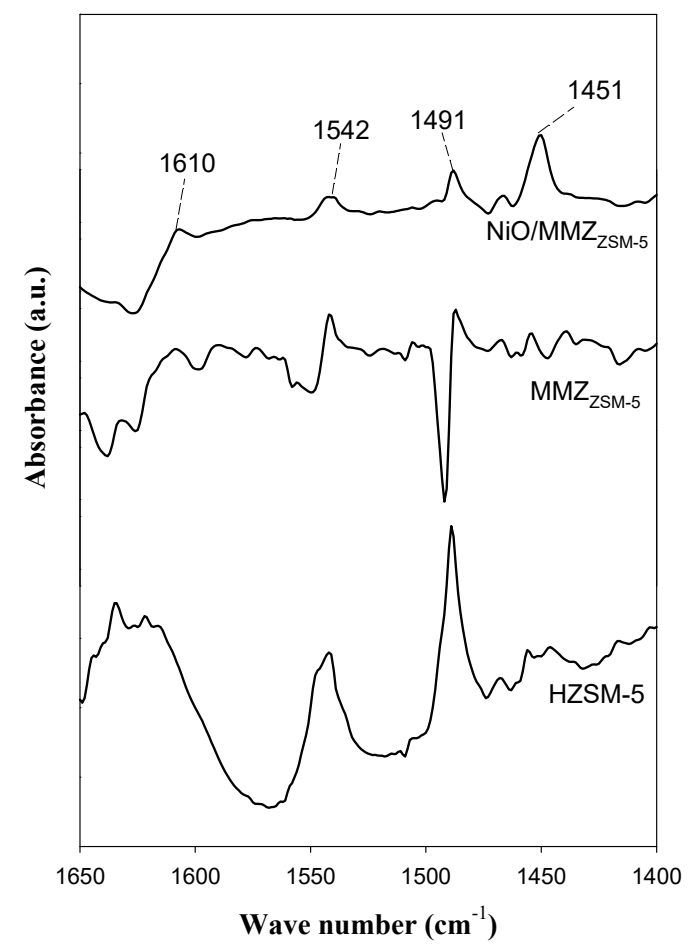

Figure 8. Pyridine-FTIR spectra at $200^{\circ} \mathrm{C}$ under a vacuum over various catalysts.

\subsection{Oligomerization of Mixed-Butene}

The HZSM-5 catalyst showed good stability for butene oligomerization (Figure 9). In previous studies on trimerization of iso-butene, it was proposed that the catalytic performance of solid acid catalysts and zeolites could be altered by their pore geometry [21,22]. The most common finding is that medium-pore molecular sieves, such as zeolite MFI and zeolite beta, were shown to be suitable for oligomerization of iso-butene or n-butene into diesel and gasoline fuels due to their shape-selective properties [20,35]. Besides that, these zeolite catalysts were proved to have high coke-resistance due to limited polyaromatic generation in their pore structure. Based on similar analogies, the stability of HZSM- 5 catalyst during the conversion of the butene mixture into $\mathrm{C}_{8}-\mathrm{C}_{16}$ hydrocarbon could be due to the coke-resistance resulting from the pore geometry. 


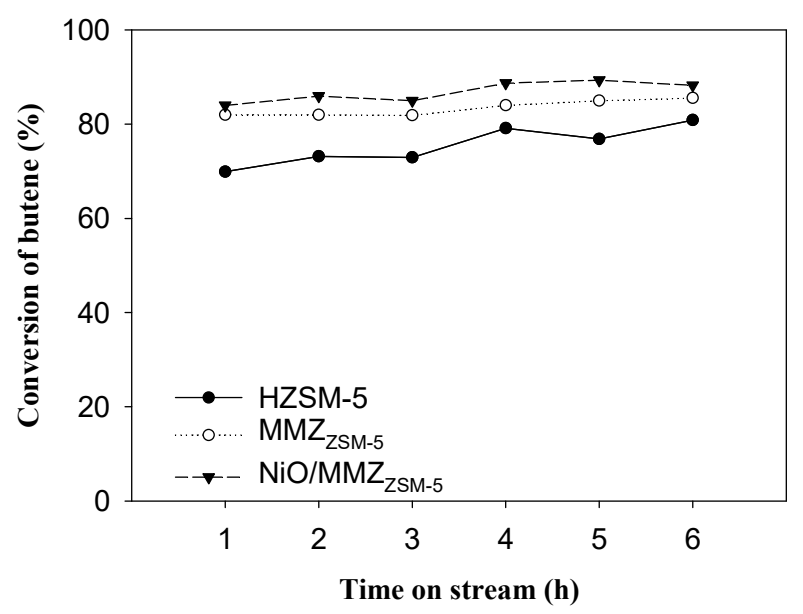

Figure 9. Conversion of butene through the oligomerization of a butene mixture over various catalysts (Reaction condition: pressure $1.5 \mathrm{MPa}$, temperature $350{ }^{\circ} \mathrm{C}$, WHSV $10 \mathrm{~h}^{-1}$ ).

After the reaction had progressed for six hours, the $\mathrm{MMZ}_{\mathrm{ZSM}-5}$ catalyst showed much higher butene conversion and $\mathrm{C}_{8}-\mathrm{C}_{16}$ yield than those with HZSM-5 (Figures 9 and 10). From the $\mathrm{NH}_{3}-\mathrm{TPD}$ and Pyridine-FTIR results, MMZ $Z_{\mathrm{ZSM}-5}$ was found to have fewer and weaker acidities than HZSM-5 catalyst. Thus, it is presumed that the reason why the $M \mathrm{MMZ}_{\mathrm{ZSM}-5}$ catalyst is beneficial for butene oligomerization, despite the fact that the acidity of $\mathrm{MMZ}_{\mathrm{ZSM}-5}$ is inferior to HZSM-5, is its pore geometry. $M M Z_{\mathrm{ZSM}-5}$ has an average pore size of $2.7 \mathrm{~nm}$, which is much larger than the pore size $(0.5-0.6 \mathrm{~nm})$ of HZSM- 5 . Consequently, it can be suggested that the mesoporous structure of $\mathrm{MMZ}_{\mathrm{ZSM}-5}$ plays an important role in overcoming the internal pore diffusion of the molecules participating in the reaction.

Moreover, the yield for $\mathrm{C}_{8}-\mathrm{C}_{16}$ hydrocarbons over $\mathrm{NiO} / \mathrm{MMZ}_{\mathrm{ZSM}-5}$ was higher than that over the $\mathrm{MMZ}_{\mathrm{ZSM}-5}$ (Figures 9 and 10). The pore size distributions of the two catalysts were not significantly different. On the other hand, according to the $\mathrm{NH}_{3}$-TPD and pyridine-FTIR analysis, it can be confirmed that when $\mathrm{NiO}$ is loaded on $\mathrm{MMZ}_{\mathrm{ZSM}-5}$, the Lewis acid sites become more abundant and the acid strength becomes stronger. Therefore, the higher butene conversion over $\mathrm{NiO} / \mathrm{MMZ}_{\mathrm{ZSM}-5}$ catalysts seemed to be due to higher acid strength resulting from a higher Lewis site-to-Brønsted site ratio. Consequently, it may be summarized that mesoporous structures, as well as the high ratio of Lewis to Brønsted acid, were beneficial for production of $\mathrm{C}_{8}-\mathrm{C}_{16}$ hydrocarbons through butene oligomerization.

The carbon number distribution in the aviation fuel range $\left(\mathrm{C}_{8}-\mathrm{C}_{16}\right.$ hydrocarbons) was not significantly influenced by the catalysts (Figure 11). In our previous study, it was found that dimers were the main reaction products at a low butane conversion over the zeolite catalysts [26]. In this study, because the butene conversion was high over three catalysts, the carbon number distribution in the range of $\mathrm{C}_{8}-\mathrm{C}_{16}$ hydrocarbon became broader, which is ascribed to the contribution of consecutive cracking and subsequent oligomerization pathways. 


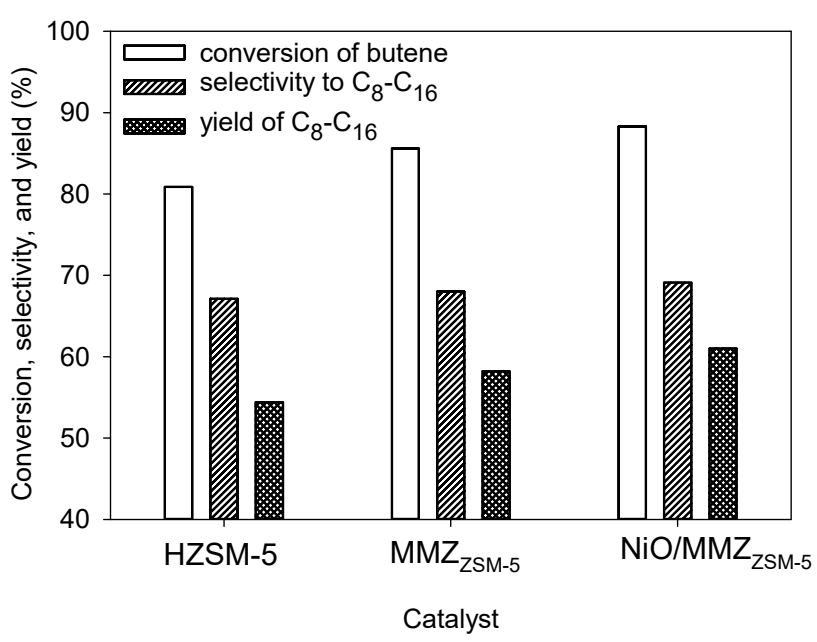

Figure 10. Conversion of butene, selectivity to $C_{8}-C_{16}$ fraction, and yield of $C_{8}-C_{16}$ fraction over various catalysts (reaction condition: pressure $1.5 \mathrm{MPa}$, temperature $350{ }^{\circ} \mathrm{C}, \mathrm{WHSV} 10 \mathrm{~h}^{-1}$, and T-O-S 6 h).

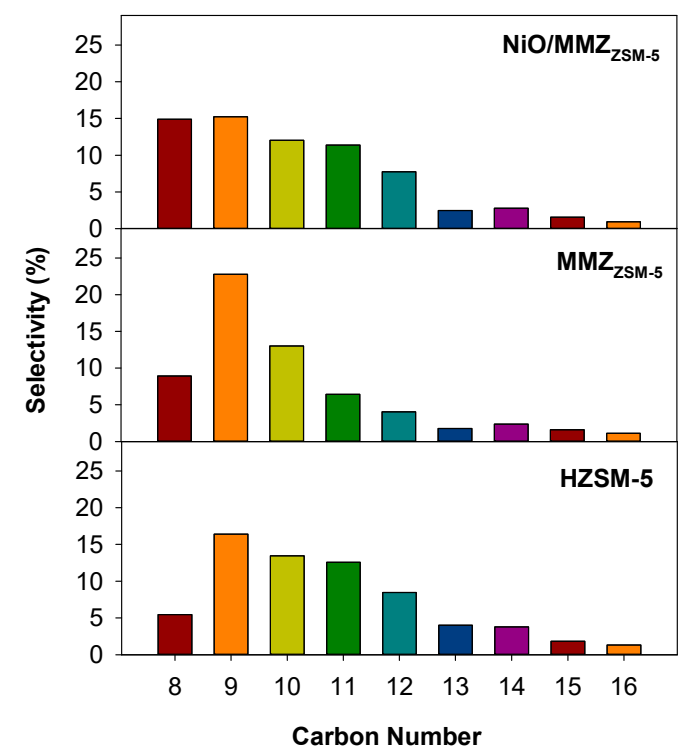

Figure 11. Product distribution of the $C_{8}-C_{16}$ range through the oligomerization of a butene mixture over various catalysts (reaction condition: pressure $1.5 \mathrm{MPa}$, temperature $350{ }^{\circ} \mathrm{C}, \mathrm{WHSV} 10 \mathrm{~h}^{-1}$, T-O-S 6 h).

Catalytic stability of the $\mathrm{NiO} / \mathrm{MMZ}_{\mathrm{ZSM}-5}$ catalyst was evaluated under $1.5 \mathrm{MPa}$ at $350{ }^{\circ} \mathrm{C}$ for $30 \mathrm{~h}$ on stream (Figure 12). The conversion of butene was more than $80 \%$ and did not decrease significantly for $18 \mathrm{~h}$ on stream. However, the $\mathrm{NiO} / \mathrm{MMZ}_{\mathrm{ZSM}-5}$ catalyst exhibited a decrease in butene conversion after $18 \mathrm{~h}$ of time-on-stream (TOS) while having no significant drop in selectivity to $\mathrm{C}_{8}-\mathrm{C}_{16}$ fraction with TOS. As a result, the yield of $\mathrm{C}_{8}-\mathrm{C}_{16}$ hydrocarbon remained above $63 \%$ for $18 \mathrm{~h}$ TOS, then gradually decreased to $48.0 \%$ after $30 \mathrm{~h}$ TOS.

To quantify the coke deposits formed on the $\mathrm{NiO} / \mathrm{MMZ}_{\mathrm{ZSM}-5}$ catalyst after reaction for $30 \mathrm{~h}$, the weight contents of these deposits were determined by TGA. According to Figure 13, two ranges of weight losses can be recognized: a low-temperature region at $<100{ }^{\circ} \mathrm{C}$ and a high-temperature region at $>400{ }^{\circ} \mathrm{C}$, which could be attributed to volatile organic compounds and coke deposits, respectively. Consequently, it was found that about $4 \mathrm{wt} \%$ of coke was formed on the $\mathrm{NiO} / \mathrm{MMZ}$ ZSM-5 catalyst after TOS of $30 \mathrm{~h}$. 


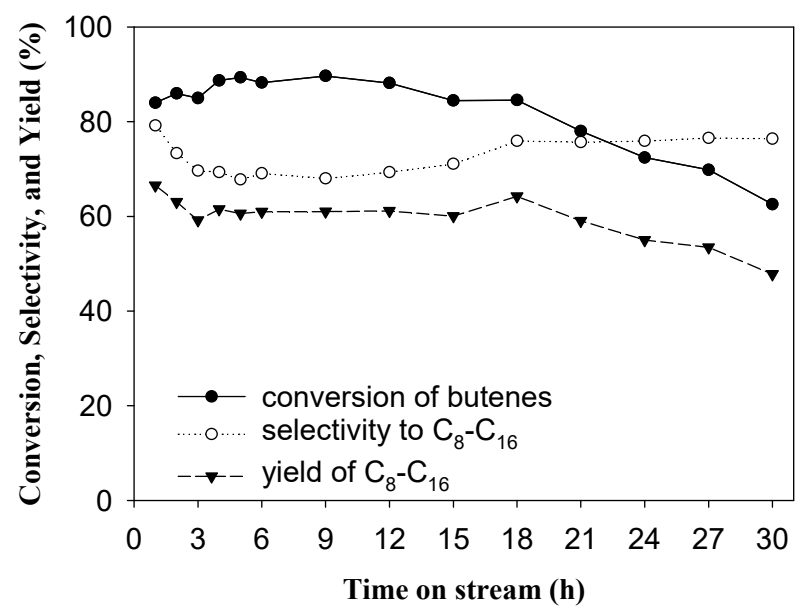

Figure 12. Conversion of butene, selectivity to $C_{8}-C_{16}$ fraction, and yield of $C_{8}-C_{16}$ fraction over $\mathrm{NiO} / \mathrm{MMZ}_{\mathrm{ZSM}-5}$ catalyst for TOS up to $30 \mathrm{~h}$ (reaction condition: pressure $1.5 \mathrm{MPa}$, temperature $350{ }^{\circ} \mathrm{C}$, and WHSV $10 \mathrm{~h}^{-1}$ ).

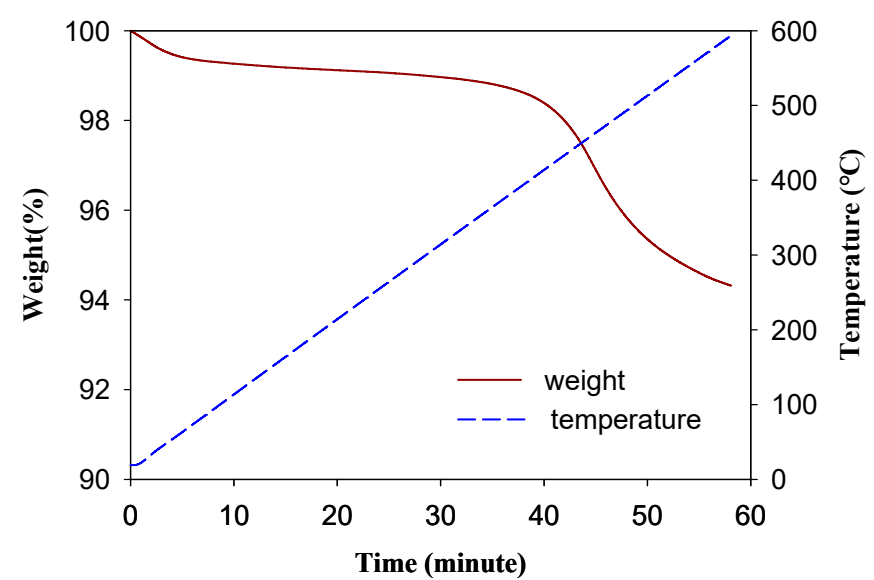

Figure 13. Degradation temperature measurement of the spent $\mathrm{NiO} / \mathrm{MMZ}_{\mathrm{ZSM}-5}$ catalyst.

\section{Materials and Methods}

\subsection{Preparation of Catalysts}

The procedure of the catalyst preparation consists of the top-down and bottom-up approaches [13,27]. A cationic surfactant and HZSM-5 zeolite were used as the template and the framework sources, respectively. At first, HZSM-5 is rent into nano-unit in alkali solution (top-down approach). $\mathrm{NaOH}$ $(0.375 \mathrm{~mol})$ was dissolved in $76.5 \mathrm{~mL}$ of deionized water to prepare $\mathrm{NaOH}$ aqueous solution $(4.9 \mathrm{M}$, $80.0 \mathrm{~mL}$ ), and then $33.75 \mathrm{~g}$ of HZSM-5 (Zeolyst, $\mathrm{SiO}_{2} / \mathrm{Al}_{2} \mathrm{O}_{3}$ mole ratio $\left.=50\right)$ was mixed into the $\mathrm{NaOH}$ aqueous solution and stirred for $1 \mathrm{~h}$. Subsequently, this zeolitic nano-unit is assembled into ordered mesoporous material using the template (bottom-up approach). Hexadecyltrimethylammonium bromide $(0.189 \mathrm{~mol})$ was dissolved into $1050 \mathrm{~mL}$ of deionized water, and the HZSM-5 solution was added drop-by-drop. This mixture was stirred for $24 \mathrm{~h}$, and the $\mathrm{pH}$ was controlled to 10 using $\mathrm{CH}_{3} \mathrm{COOH}$ solution (50\%). After $\mathrm{pH}$ adjustment and mixing were repeated three times, a white precipitate was obtained. The resulting products were dried at $110{ }^{\circ} \mathrm{C}$ overnight and calcined at $550{ }^{\circ} \mathrm{C}$ for $4 \mathrm{~h}$ in an air atmosphere to obtain a mesoporous aluminosilicate material. Subsequently, it was ion-exchanged using $\mathrm{NH}_{4} \mathrm{Cl}$ aqueous solution $(1 \mathrm{M})$ to convert to the $\mathrm{NH}_{4}{ }^{+}$form and again converted to $\mathrm{H}^{+}$form by calcination in an air atmosphere at $550{ }^{\circ} \mathrm{C}$ for $3 \mathrm{~h}$. The newly prepared material was named $\mathrm{MMZ}_{\mathrm{ZSM}-5}$, meaning mesoporous material from ZSM-5. 
Nickel nitrate hexahydrate $(98.0 \%)$ was impregnated on $\mathrm{MMZ}_{\mathrm{ZSM}-5}$ catalyst by the dry impregnation method. The loading amount of nickel metal was $3 \mathrm{wt} \%$. After calcination in an air atmosphere at $550{ }^{\circ} \mathrm{C}$ for $3 \mathrm{~h}$, the $\mathrm{NiO} / \mathrm{MMZ}_{\mathrm{ZSM}-5}$ catalyst was obtained.

\subsection{Characterization of Catalysts}

The nitrogen physisorption isotherms of the catalysts were obtained using a BELSORP-mini II device (BEL Japan Inc., Toyonaka, Japan) at $-196^{\circ} \mathrm{C}$. XRD patterns of the catalysts were collected at $40 \mathrm{kV}$ and $40 \mathrm{~mA}$ using a D/MAX-2200V Diffractometer (Rigaku Co., The Woodlands, TX, USA), and data were reduced using the JADE program. TEM images were collected using a JEM-3010 (JEOL, Tokyo, Japan) operated at $300 \mathrm{kV}$.

The $\mathrm{NH}_{3}$-TPD was performed using BEL-CAT-B device (BEL Japan Inc., Toyonaka, Japan). The sample was outgassed at $550{ }^{\circ} \mathrm{C}$ in a He gas flow $(50 \mathrm{~mL} / \mathrm{min})$ for an hour. The ammonia $(5 \%$ in $\mathrm{He}$ ) was adsorbed on the sample, and then the physically adsorbed ammonia was desorbed in a He gas flow ( $50 \mathrm{~mL} / \mathrm{min}$ ) for $2 \mathrm{~h}$. Subsequently, the amount of ammonia desorbed was detected by a thermal conductivity detector while increasing the temperature of sample holder from 100 to $550{ }^{\circ} \mathrm{C}$ at a heating rate of $10^{\circ} \mathrm{C} / \mathrm{min}$.

FTIR spectra of adsorbed-pyridine were attained with a Spectrum GX device (Perkin Elmer Co., Waltham, MA, USA) equipped with an HgCdTe detector and a custom-made cell. FTIR spectra of pyridine adsorbed on the catalyst disk were measured while the temperature of the cell was increased to $300^{\circ} \mathrm{C}[12,13]$.

In order to determine the amount of the coke over the spent catalyst, a TGA analysis was carried out using a SDT Q600 device (TA Instruments, New Castle, DE, USA). $\mathrm{N}_{2}$ was injected through a mass flow controller (model 5850E from Brooks, Hatfield, PA, USA) operated using a flow pressure controller (ATOVAC, GMC 1200, Yongin, Korea). The sample was loaded onto a Pt holder, and the volume changes and energy flow were recorded while running $\mathrm{N}_{2}(60 \mathrm{~mL} / \mathrm{min})$ and increasing the temperature up to $600{ }^{\circ} \mathrm{C}$ at a heating rate of $10^{\circ} \mathrm{C} / \mathrm{min}$.

\subsection{Oligomerization of Butene Mixture}

The oligomerization reaction of the butene mixture was conducted in a fixed-bed continuous-flow reactor [26]. The reactor set-up and the experimental procedures for butene oligomerization were described in detail in the literature [26]. In our previous research on dehydration reaction of butanol, a mixture of butene (butene-1:butene-2 $=1.0: 1.3$ ) could be generated through dehydration of 2-butanol over a solid acid catalyst [13]. Accordingly, a mixture composed of $43.5 \%$ of butene- 1 (99\%, Rigas Korea Co., Daejeon, Korea) and 56.5\% of butene-2 (11.8\% of cis-2-butene and $87.5 \%$ of trans-2-butene, Rigas Korea Co., Daejeon, Korea) was used as a model reactant. The particle size of the catalyst was $25 \mu \mathrm{m}$ or less. The reaction pressure and temperature were $15 \mathrm{bar}$ and $350{ }^{\circ} \mathrm{C}$, respectively, unless otherwise specified. In this study, most of the reaction products were alkene compounds. Needless to say, in order to use this product as a fuel, it must be converted to a paraffin compound via a hydrogenation reaction. The selectivity to $C_{8}-C_{16}$ hydrocarbons was calculated based on the alkenes in the range of $C_{8}-C_{16}$. The formulae for the conversion of butene, the selectivity to $C_{8}-C_{16}$ hydrocarbons, and the yield of $\mathrm{C}_{8}-\mathrm{C}_{16}$ hydrocarbons are as follows:

$$
\begin{gathered}
\text { Conversion of butene (wt } \%)=(\text { consumed butene } / \text { fed butene }) * 100 \\
\text { Selectivity of } C_{8}-C_{16}(w t \%)=\left(C_{8}-C_{16} \text { product } / \text { consumed butene }\right) * 100 \\
\text { Yield of } C_{8}-C_{16}(w t \%)=\left(C_{8}-C_{16} \text { product } / \text { fed butene }\right) * 100
\end{gathered}
$$




\section{Conclusions}

Mesoporous aluminosilicate with a well-ordered structure was successfully prepared from HZSM- 5 by combining a top-down method and a bottom-up method. The ordered channel-like mesopores were maintained after the nickel-loading on $\mathrm{MMZ}_{\mathrm{ZSM}-5}$ catalyst. The $\mathrm{NH}_{3}-\mathrm{TPD}$ and pyridine-FTIR results revealed that a new kind of acid site (Lewis acid sites) was generated by $\mathrm{NiO}$ loading on $\mathrm{MMZ}_{\mathrm{ZSM}-5}$. The $\mathrm{MMZ}_{\mathrm{ZSM}-5}$ catalyst showed much higher butene conversion and $\mathrm{C}_{8}-\mathrm{C}_{16}$ yield in the butene oligomerization reaction than those with HZSM- 5 . This is attributed to the pore geometry of $\mathrm{MMZ}_{\mathrm{ZSM}-5}$, which is more beneficial for internal diffusion of reactants, reaction intermediates, and products. Moreover, the yield for $\mathrm{C}_{8}-\mathrm{C}_{16}$ hydrocarbons over $\mathrm{NiO} / \mathrm{MMZ} \mathrm{ZSM}_{\mathrm{Z}-5}$ was higher than that over the $M M Z_{Z S M-5}$, which seemed to be due to higher acid strength resulting from a higher ratio of Lewis sites to Brønsted sites. The present study reveals that mesoporous $\mathrm{NiO} / \mathrm{MMZ}_{\mathrm{ZSM}-5}$ catalyst with high concentration of Lewis acid sites is a potential catalyst for production of $\mathrm{C}_{8}-\mathrm{C}_{16}$ hydrocarbons through the oligomerization of a butene mixture.

Author Contributions: D.L. and H.K. performed experiments; D.L., H.K., Y.-K.P., and J.-K.J. collected and analyzed data; and D.L. and J.-K.J. wrote the manuscript.

Funding: This research was supported by Basic Science Research Program through the National Research Foundation of Korea (NRF) funded by the Ministry of Education (NRF-2015R 1D 1A 1A01058354). This work was also supported by "Human Resources Program in Energy Technology" of the Korea Institute of Energy Technology Evaluation and Planning (KETEP), granted financial resource from the Ministry of Trade, Industry \& Energy, Republic of Korea (No. 20174010201560).

Conflicts of Interest: The authors declare no conflict of interest.

\section{References}

1. Fearnside, P.M. Global Warming and tropical land-use change: Greenhouse gas emissions from biomass burning, decomposition and soils in forest conversion, shifting cultivation and secondary vegetation. Clim. Chang. 2000, 46, 115-158. [CrossRef]

2. Sheldon, R.A. Green and sustainable manufacture of chemicals from biomass: State of the art. Green Chem. 2014, 16, 950-963. [CrossRef]

3. Wang, W.C.; Tao, L. Bio-aviation fuel conversion technologies. Renew. Sustain. Energy Rev. 2016, 53, 801-822. [CrossRef]

4. Wright, M.E.; Harvey, B.G.; Quintana, R.L. Highly efficient zirconium-catalyzed batch conversion on 1-butene: A new route to aviation fuels. Energy Fuels 2008, 22, 3299-3302. [CrossRef]

5. Wright, M.E.; Harvey, B.G.; Quintana, R.L. Diesel and Aviation Fuels Based on the oligomerization of butene. U.S. Patent US8395007B2, 12 March 2013.

6. Matthew, W.P.; Taylor, J.D. Renewable Aviation Fuel Blendstock from Isobutanol. U.S. Patent US8373012B2, 12 February 2013.

7. Wright, M.E. Process for the Dehydration of Aqueous Bio-Derived Terminal Alcohols to Terminal Alkenes. U.S. Patent US8912373B2, 16 December 2014.

8. Zakaria, Z.Y.; Linnekoski, J.; Amin, N.A.S. Catalyst screening for conversion of glycerol to light olefins. Chem. Eng. J. 2012, 207-208, 803-813. [CrossRef]

9. Korstanje, T.J.; Jastrzebski, J.T.B.H.; Kleingebbink, R.J.M. Mechanistic insights into the rhenium-catalyzed alcohol-to-olefin dehydration reaction. Chem. A Eur. J. 2013, 19, 13224-13234. [CrossRef] [PubMed]

10. Kamiguchi, S.; Nagashima, S.; Komori, K.I.; Kodomari, M.; Chihara, T. Thermal activation of molecular tungsten halide clusters with the retention of an octahedral metal framework and the catalytic dehydration of alcohols to olefins as a solid acid catalyst. J. Clust. Sci. 2007, 18, 414-430. [CrossRef]

11. Lee, I.C.; Clair, J.G.S.; Gamson, A.S. Catalytic Oxidative Dehydration of Butanol Isomers: 1-Butanol, 2-Butanol, and Isobutanol; Army Research Laboratory: Adelphi, MD, USA, 2011.

12. Choi, H.; Bae, J.H.; Kim, D.H.; Park, Y.K.; Jeon, J.K. Butanol dehydration over $\mathrm{V}_{2} \mathrm{O}_{5}-\mathrm{TiO}_{2} / \mathrm{MCM}-41$ catalysts prepared via liquid phase atomic layer deposition. Materials 2013, 6, 1718-1729. [CrossRef] [PubMed] 
13. Jeong, S.; Kim, H.; Bae, J.H.; Kim, D.H.; Peden, C.H.F.; Park, Y.K.; Jeon, J.K. Synthesis of butenes through 2-butanol dehydration over mesoporous materials produced from ferrierite. Catal. Today 2012, 185, $191-197$. [CrossRef]

14. Coelho, A.; Caeiro, G.; Lemos, M.; Lemos, F.; Ribeiro, F.R. 1-butene oligomerization over ZSM-5 zeolite: Part 1-Effect of reaction conditions. Fuel 2013, 111, 449-460. [CrossRef]

15. Golombok, M.; de Bruijn, J. Dimerization of n-butenes for high octane gasoline components. Ind. Eng. Chem. Res. 2000, 39, 267-271. [CrossRef]

16. Zhang, L.; Ke, M.; Song, Z.; Liu, Y.; Shan, W.; Wang, Q.; Xia, C.; Li, C.; He, C. Improvement of the catalytic efficiency of butene oligomerization using alkali metal hydroxide-modified hierarchical ZSM-5 Catalysts. Catalysts 2018, 8, 298. [CrossRef]

17. Kocaman, E.; Akarçay, Ö.; Bağlar, N.; Çelebi, S.; Uzun, A. Isobutene oligomerization on MCM-41-supported tungstophosphoric acid. Mol. Catal. 2018, 457, 41-50. [CrossRef]

18. Nadolny, F.; Hannebauer, B.; Alscher, F.; Peitz, S.; Reschetilowski, W.; Franke, R. Experimental and theoretical investigation of heterogeneous catalyzed oligomerization of a mixed $\mathrm{C}_{4}$ stream over modified amorphous aluminosilicates. J. Catal. 2018, 367, 81-94. [CrossRef]

19. Li, C.; Wang, H.; Zhu, S.; Liu, G.; Wu, J. Research on butene oligomerization reaction over the hemicellulose modified HZSM-5. J. Fuel Chem. Technol. 2017, 45, 1088-1094. [CrossRef]

20. Yoon, J.W.; Chang, J.S.; Lee, H.; Kim, T.J.; Jhung, S.H. Trimerization of isobutene over a zeolite beta catalyst. J. Catal. 2007, 245, 253-256. [CrossRef]

21. Yoon, J.W.; Chang, J.S.; Lee, H.D.; Kim, T.J.; Jhung, S.H. Trimerization of isobutene over cation exchange resins: Effect of physical properties of the resins and reaction conditions. J. Mol. Catal. A Chem. 2006, 260, 181-186. [CrossRef]

22. Yoon, J.W.; Jhung, S.H.; Chang, J.S. Trimerization of isobutene over solid acid catalysts: Comparison between cation-exchange resin and zeolite catalysts. Bull. Korean Chem. Soc. 2008, 29, 339-341.

23. Mantilla, A.; Ferrat, G.; López-Ortega, A.; Romero, E.; Tzompantzi, F.; Torres, M.; Ortíz-Islas, E.; Gómez, R. Catalytic behavior of sulfated $\mathrm{TiO}_{2}$ in light olefins oligomerization. J. Mol. Catal. A Chem. 2005, 228, 333-338. [CrossRef]

24. Zhang, X.; Zhong, J.; Wang, J.; Gao, J.; Liu, A. Trimerization of butene over Ni-doped zeolite catalyst: Effect of textural and acidic properties. Catal. Lett. 2008, 126, 388-395. [CrossRef]

25. Zhang, X.; Zhong, J.; Wang, J.; Zhang, L.; Gao, J.; Liu, A. Catalytic performance and characterization of Ni-doped HZSM-5 catalysts for selective trimerization of n-butene. Fuel Process. Technol. 2009, 90, 863-870. [CrossRef]

26. Kim, H.; Kim, D.; Park, Y.K.; Jeon, J.K. Synthesis of aviation fuel through the oligomerization of butenes on zeolite catalysts. Res. Chem. Intermed. 2018, 44, 3823-3833. [CrossRef]

27. Lee, H.I.; Park, H.J.; Park, Y.K.; Hur, J.Y.; Jeon, J.K.; Kim, J.M. Synthesis of highly stable mesoporous aluminosilicates from commercially available zeolites and their application to the pyrolysis of woody biomass. Catal. Today 2008, 132, 68-74. [CrossRef]

28. Bagshaw, S.A.; Baxter, N.I.; Brew, D.R.M.; Hosie, C.F.; Yuntong, N.; Jaenicke, S.; Khuan, C.G. Highly ordered mesoporous MSU-SBEA/zeolite Beta composite material. J. Mater. Chem. 2006, 16, 2235-2244. [CrossRef]

29. Thommes, M.; Kaneko, K.; Neimark, A.V.; Olivier, J.P.; Rodriguez-Reinoso, F.; Rouquerol, J.; Sing, K.S.W. Physisorption of gases, with special reference to the evaluation of surface area and pore size distribution (IUPAC Technical Report). Pure Appl. Chem. 2015, 87, 1051-1069. [CrossRef]

30. Alothman, Z.A. A review: Fundamental aspects of silicate mesoporous materials. Materials 2012, 5, $2874-2902$. [CrossRef]

31. Lee, H.I.; Kim, J.M.; Lee, J.Y.; Park, Y.K.; Jeon, J.K.; Yim, J.H.; Park, S.H.; Lee, K.J.; Kim, S.S.; Jeong, K.E. Catalytic conversion of 1,2-dichlorobenzene over mesoporous materials from zeolite. J. Nanosci. Nanotechnol. 2010, 10, 3639-3642. [CrossRef] [PubMed]

32. Yung, M.M.; Starace, A.K.; Mukarakate, C.; Crow, A.M.; Leshnov, M.A.; Magrini, K.A. Biomass catalytic pyrolysis on Ni/ZSM-5: Effects of nickel pretreatment and loading. Energy Fuels 2016, 30, 5259-5268. [CrossRef]

33. Chakraborty, B.; Viswanathan, B. Surface acidity of MCM-41 by in situ IR studies of pyridine adsorption. Catal. Today 1999, 49, 253-260. [CrossRef] 
34. Zaki, M.I.; Hasan, M.A.; Al-Sagheer, F.A.; Pasupulety, L. In situ FTIR spectra of pyridine adsorbed on $\mathrm{SiO}_{2}-\mathrm{Al}_{2} \mathrm{O}_{3}, \mathrm{TiO}_{2}, \mathrm{ZrO}_{2}$ and $\mathrm{CeO}_{2}$ : General considerations for the identification of acid sites on surfaces of finely divided metal oxides. Colloids Surf. A Physicochem. Eng. Asp. 2001, 190, 261-274. [CrossRef]

35. Popov, A.G.; Pavlov, V.S.; Ivanova, I.I. Effect of crystal size on butenes oligomerization over MFI catalysts. J. Catal. 2016, 335, 155-164. [CrossRef]

(C) 2018 by the authors. Licensee MDPI, Basel, Switzerland. This article is an open access article distributed under the terms and conditions of the Creative Commons Attribution (CC BY) license (http:/ / creativecommons.org/licenses/by/4.0/). 